\title{
Zmienna przestrzeń teatralna a synergia
}

\author{
Piotr Obracaj \\ Katedra Budownictwa i Architektury, Wydzial Budownictwa i Architektury, \\ Politechnika Opolska, e-mail: p.obracaj@po.opole.pl
}

Streszczenie: Poszukiwanie rozwiązania sceno-widowni dającego możliwie szerokie możliwości aranżacyjne, było domeną lat 60 i 70-tych XX wieku. W owym czasie powstało najwięcej projektów i realizacji scenicznych, w których możliwe były do zaaranżowania podstawowe relacje terenów gry i obserwacji, zatem barokowy włoski, otwarty i arenowy. Tendencja ta na przełomie wieków zanikła, nastąpił natomiast renesans sceny włoskiej w różnych odmianach, z zasady o niezmiennej formie, czasem z niewielkimi możliwościami transformacji na linii opera - koncert - teatr dramatyczny. Wszystkie te rozwiązania generowały ogromne koszty poprzez konieczność zastosowania niestandardowych urządzeń technicznych, również znacząco podrażających eksploatację. W 1996/1997 roku w Londynie otwarto zrekonstruowany szekspirowski teatr „Globe”. Obiekt ten niewątpliwie dał początek odrodzonej wizji współczesnego teatru dramatycznego. Forma przestrzenna, nawiązująca do starożytności, z pozoru nie wydaje się mobilna inscenizacyjnie. Jednakże z punktu widzenia szczególnej relacji widza i aktora, stosując odpowiednie kryteria reżyserskie, układ zyskuje ,wewnętrzną” zmienność przy praktycznie niezmienionym układzie przestrzennym. Idea teatru renesansowej Anglii w pierwszym rzędzie ma zastosowanie w obiektach masowych, otwartych. Dyskusyjne są rozwiązania, w których stosuje się otwierany dach, czy rozbudowaną w tle ,języka” scenicznego namiastkę sceny pudełkowej. W końcu wznoszenie obiektu w ciężkiej, żelbetowej konstrukcji, a nie w lekkiej, drewnianej, powoduje zaniżenie „efektywności” inscenizacyjnej, koszty natomiast rosną. Surowość formalna teatru elżbietańskiego przy wymaganiach technicznych odnoszących się głównie do bazy oświetleniowej, jest akceptowalna w szerokim zakresie repertuarowym. Przy niewielkich nakładach finansowych i zgodnym współdziałaniu architektów i inscenizatorów z przypisanymi im branżami, całkowicie spełnia się zasada synergii.

Słowa kluczowe: zmienna przestrzeń teatralna, teatr elżbietański, scena pudełkowa, tereny gry i obserwacji.

\section{Wprowadzenie}

Pojęcie ,zmienna przestrzeń teatralna” stało się modne w latach siedemdziesiątych poprzedniego stulecia. Zarówno nowe obiekty teatralne, jak i modernizowane istniejące, podciągano pod schemat: duża scena operowa (dramatyczna) i mała scena określana jako eksperymentalna. Ta druga najczęściej tworzyła układ otwarty tzn. otaczano ją widownią w granicach 3/5 obwodu. Forma ta, nawiązująca do starożytności, stwarzała warunki do zmienności. Poprzez brak bariery w postaci mostu portalowego, dawała się elastycznie kształtować umowną dekoracją, co pozwalało na swobodną aranżację akcji scenicznej. Zmienność przestrzeni wynikała zatem z formuły inscenizacyjnej, przyjętej przez reżysera.

Równolegle powstawało szereg projektów obiektów teatralnych, w których w głównej sali można było uzyskać różne warianty relacji sceny i widowni, szerzej: terenów gry 
i obserwacji. Większość koncepcji trafiała „na półkę”, najczęściej ze względu na zbyt wysokie koszty realizacji. Wznoszono obiekty o prestiżowym charakterze, niekoniecznie kierując się rzeczywistą potrzebą. W późniejszej praktyce scenicznej możliwe wariantowanie przestrzeni ograniczało się do podstawowych uformowań opartych na schemacie barokowym włoskim. Dominował najczęściej jako podstawowy. Kolejne warianty użytkowania to scena otwarta i arena. W zależności od przyjętego systemu przekształceń, możliwe były rożne kombinacje tych trzech układów. Stosowana na powierzchni całej scenowidowni gęsta siatka zapadni, rozpięty nad nią strop techniczny oraz możliwości regulacji wielkością kubatury poprzez ruchome moduły ścienne, to standardowy zestaw środków technicznych, do których jeszcze należy dodać szeroką już wówczas ofertę demontowanych siedzisk. Równolegle z rozszerzaniem możliwości zmienności przestrzeni dla teatru, rosła cena inwestycji. Artyści teatru odnosili się do tak dalece zaawansowanych technicznie rozwiązań z dużą rezerwą. Sale teatralne często uważano za bliskie halom fabrycznym. Powoli, ze wszystkich stosowanych technologii w kreacji przedstawienia teatralnego na pierwszy plan wysunęło się światło, które z czasem znalazło się na liście potrzeb artysty teatru na pierwszym miejscu, zaraz za możliwie neutralną formą sceno-widowni. Inscenizatorzy sprzeciwiali się przestrzeniom, w których wyeksponowanie techniki mogłoby istotnie wpływać na odbiór przedstawienia.

\section{Rozwiązania techniczne dla przestrzeni zmiennej. Teatr elżbietański/szekspirowski}

W 1978 roku w Paryżu arch. Valentin Fabre i Jean Perrotet wraz ze scenografem Bernardem Guillaumot w przyziemiu pałacu Chaillot wbudowali „fabrykę” do robienia przedstawień. Zastosowali w niej wszelkie środki służące zmienności przestrzeni. Można zauważyć konsekwencję, systemowość i pewne wyrafinowanie w zastosowaniu urządzeń, jednakże wnętrze, przy każdym wariancie scenicznym, przypomina halę fabryczną. Prapremiera ostatniego przedstawienia Tadeusza Kantora „Nigdy tu już nie powrócę” odbyła się w mediolańskim Teatro Piccolo w 1988 roku. Kilka miesięcy później artysta zdecydował się na spektakl w paryskim Chaillot. Symboliczne nakrycie aktorów czarnym suknem w finale przedstawienia, korespondowało $\mathrm{z}$ charakterem nasyconego techniką wnętrza, które w tym przypadku współtworzyło oczekiwanego przez twórcę „ducha” przedstawienia. T. Kantora nie interesowały inne relacje sceno-widowni, jakie możliwe były w tej przestrzeni, ponieważ zmienność przez niego wykreowana dokonywała się w obrębie sceny, przy stałej widowni o jednym kierunku obserwacji. Stąd ów, teatr śmierci” można by określić mianem „totalnego”, biorąc pod uwagę wielorakość środków wyrazu. Należy to pojmować w kategoriach totalnego wymiaru teatru uczestników.

W latach trzydziestych poprzedniego stulecia Walter Gropius i Erwin Piscator wspólnie wykreowali przestrzeń, którą nazwali teatrem totalnym. Zmienność oparta została na środkach technicznych, jednakże pojęcie „totalny” bliższe jest rozumieniu jego treści przez polskiego maga teatru, aniżeli technologii zmienności w Chaillot. Poprzez obrót centralnej części widowni twórcy uzyskali 3 podstawowe warianty sceniczne. Scena otwarta wyraźnie nawiązuje do klasycznego teatru, przy czym zakładane przez twórców bogate wyposażenie techniczne pozostaje w tle. Rozwiązanie uznać można za pierwszą przestrzeń zmienną. Określenie „totalny” odnosić należy zarówno do zmienności relacji terenów gry i obserwacji, jak i do szerokiego wachlarza możliwości i działań technicznych. Tylna projekcja na obwodzie widowni i na scenie, aranżowanie ,odcinkowych” oraz podświetlanych od tła mansjonów, to tylko niektóre $\mathrm{z}$ nich. 

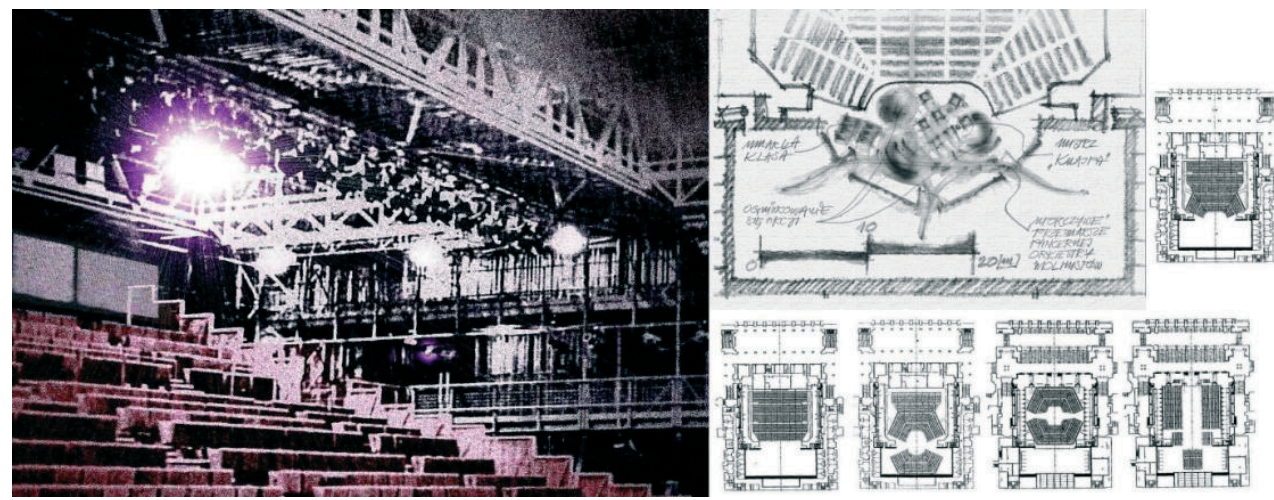

Rys. 1. Paryski teatr Chaillot, widok Sali w układzie włoskim, obok szkic aranżacji scenicznej T. Kantora do autorskiego przedstawienia „Nigdy tu już nie powrócę” i odpowiednia relacja sceno-widowni, za [1]

W niezrealizowanym berlińskim obiekcie możliwe są wszystkie dyspozytywy gry, jakie istnieją w Chaillot, technika jednak nie jest tak agresywna.

Dwa przytoczone teatry łączy masowość. Założenie takie odnosi się również do powstałego w końcu XVI wieku w Anglii budynku teatralnego, określanego jako szekspirowski, bądź elżbietański. Określenia należy traktować, jako synonimy. Kreatorem przestrzeni miał być sam William Shakespeare, natomiast inni artyści teatru działającego w renesansowej Anglii przejęli, z niewielkimi zmianami, rozwiązanie formy sceno-widowni dramaturga, zachowując wiodącą ideę przestrzenną
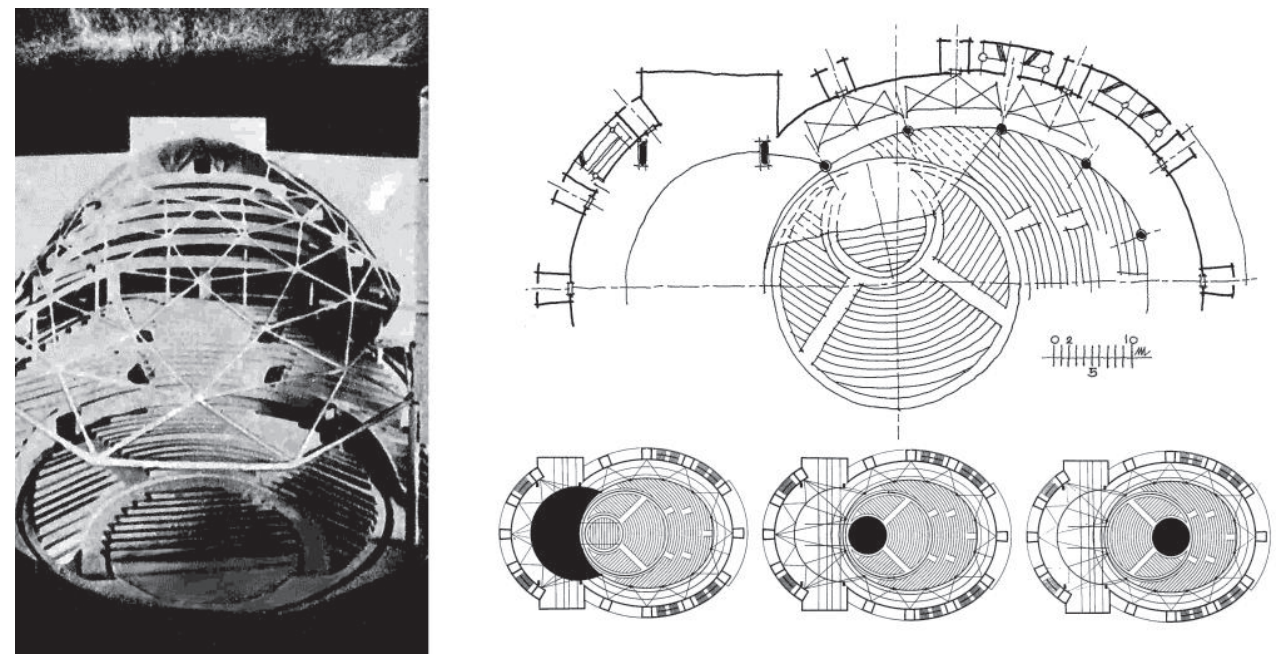

Rys. 2. Teatr totalny w. Gropiusa i E. Piscatora, czytelna zmienność przestrzeni teatralnej w granicach masowego dramatu i wzbogaconej o operę i koncert, za [1]

Teatr miał służyć masom, miał uaktywnić i wzbogacić życie kulturalne Londynu i innych dużych ośrodków miejskich. Kwestią do chwili obecnej nierozwiązaną jest pochodzenie formy. Rzut nawiązuje do formy klasycznego obiektu teatralnego, natomiast budynek przypomina rzymski obiekt widowiskowy z okresu imperialnego. Sama formuła inscenizacyjna jest już wyraźnie podporządkowana dramatowi Shakespeare`a. Twórczość innych dramaturgów epoki wydaje się bliska mu formalnie. Stąd domniemane rozwiązania teatrów 
„Swan” czy „Rose” są bliźniaczo podobne do szekspirowskiego „Globe”. Przy wszystkich niewiadomych, jak mógł być ukształtowany teatr renesansowej Anglii, jest kilka pewników, które wynikają z ryciny Johannesa de Witta i didaskaliów oraz tekstów dramatów epoki. Obiekty wznoszone były z drewna w tradycyjnej, „wyspiarskiej” konstrukcji ciesielskiej. Na podstawie wcześniejszych doświadczeń dobierano proporcje wysuniętej w kierunku widza sceny i okręgu zamykającego widownię. Jej ,pparter” z założenia przeznaczony był dla widzów stojących, natomiast na otaczających go galeriach, przeważnie w trzech poziomach, znajdowały się miejsca siedzące. Prawdopodobnie to sam Szekspir założył wielokierunkowość oglądu przedstawienia, ponieważ zarówno widzowie stojący jak i zajmujący miejsca na galeriach mogą obserwować widowisko z 3/5 obwodu koła, czyli analogicznie do teatru starożytnej Grecji. Zresztą podobieństw takich jest więcej. Frons scenae podzielona jest na dwa poziomy, z których na dolnym znajduje się troje drzwi $\mathrm{z}$ centralnym porta regalis. Akcja sceniczna może przebiegać na obydwu poziomach, nadto na wysuniętym w kierunku widzów ,języku” scenicznym można umieścić narratora i chór.

Wydaje się, że wszystkie te podobieństwa do starożytnych teatrów nie są przypadkowe. Przedstawienia w zrekonstruowanym „Globe” kreowane są na zasadzie bliskiego kontaktu widza i aktora. Spektakl „robiony” jest przy użyciu minimum „ciężkich” dekoracji, natomiast w stałym użyciu jest rekwizyt i ruchoma zastawka. Wydaje się, że formuła ,, teatr widza i aktora" jest w tym wypadku najbardziej trafną. Zmienność przestrzenna przedstawienia zawiera się $\mathrm{w}$ obrębie sceny w formie obserwacji i we wzajemnym kontakcie uczestników zdarzenia scenicznego. Aktor może wmieszać się w tłum stojących w parterze widzów, akcja spektaklu może przebiegać w dwóch, lub wliczając galerie, trzech znaczeniowych dramaturgicznie poziomach.

Scena szekspirowska/elżbietańska jest uniwersalna, spełnia kryteria zmienności przy odpowiednich założeniach inscenizacyjnych, nie ogranicza repertuaru do XVI i XVIIwiecznej Anglii. Należy ją rozpatrywać w kategoriach totalnej ze względu na tkwiące w niej możliwości inscenizacyjne.
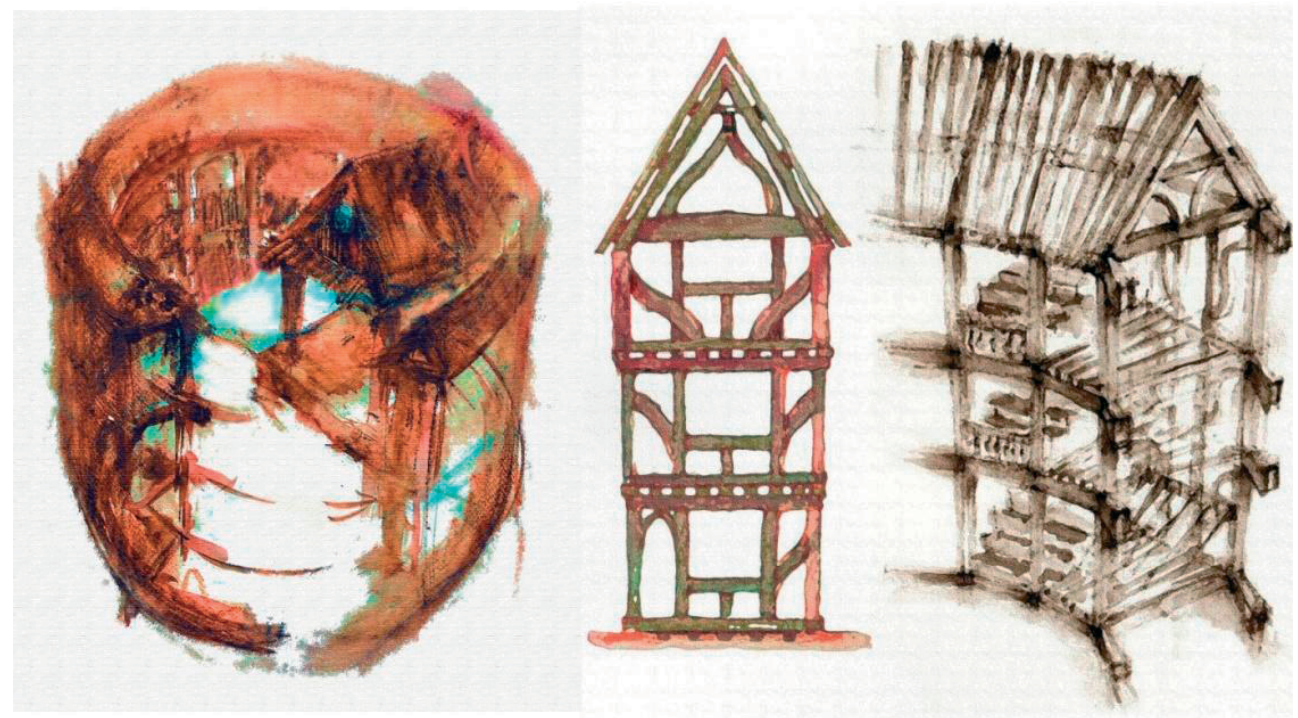

Rys. 3. XVI-wieczna konstrukcja angielskiego budynku mieszkalnego (w środku), i analogicznie zastosowana struktura w szekspirowskim/elżbietańskim teatrze, ryciny własne 
Po nastaniu rządów purytańskich teatry zostały zlikwidowane jako ,przybytki zła i rozpusty". Kontynuacji sprawdzonej formy zabrakło, z niezrozumiałą konsekwencją zostały zatarte wszelkie ślady tej znakomitej formuły scenicznej. Próby odrodzenia teatru elżbietańskiego po upadku rządów Crommwellów nie przyniosły oczekiwanych rezultatów. Teatr „Drury Lane” Christophera Wrena po kilku przebudowach zbliżył się do formy barokowej włoskiej, w takim kierunku również „rozwinęły” się poszukiwania rozwiązań scenicznych, które zostały pozytywnie zakłócone reformą teatru w drugiej połowie XIX w. i pierwszej XX wieku [2], [3] passim.

Niezależnie od reformatorskich przestrzeni teatralnych kreowanych przez Ryszarda Wagnera, Edwarda Craiga czy Adolphe Appi, szekspirowska myśl sceniczna ustawicznie powracała w różnej formie. Były to inscenizacje wpisane w scenę pudełkową, na której scenografia w powiązaniu z akcją miała współtworzyć ideę szekspirowskiego przedstawienia. Adaptowano różne przypadkowe przestrzenie, którym nadawano zbliżoną do elżbietańskiej formę rzutu. Wszelkie usiłowania upodobnienia przestrzeni scenicznej do rodzimego teatru renesansowej Anglii, teoria określa mianem „Elizabethan-in-style-theatre”. W wolnym tłumaczeniu należy interpretować to jako „, teatr w stylu elżbietańskim” bądź trafniej „teatr nawiązujący formułą do elżbietańskiego”. Rzeczywista, szekspirowska idea teatru podporządkowana jest ścisłym regułom przestrzennym. Wszelkie uchybienia funkcjonalno-formalne dają inne efekty sceniczne, mogą powodować utratę istotnych walorów inscenizacyjnych.
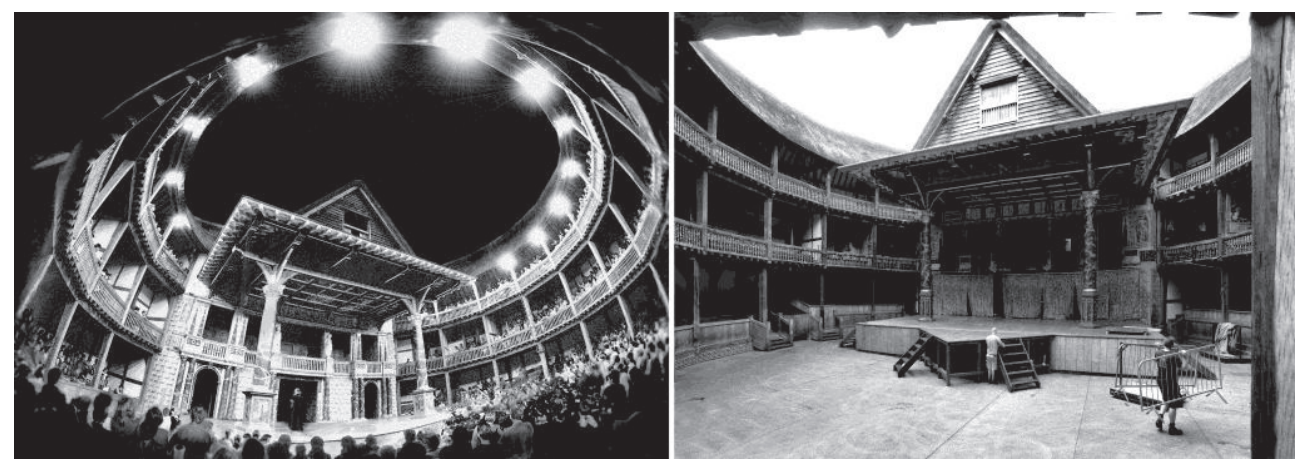

Rys. 4. „Ryszard II” na scenie Globe oraz pomost dla Prospera w „Burzy” Shakespeare’a, zdjęcia własne autora

Z badań nad teatrem renesansowej Anglii wynika, że znaczące teatry, które powstały wówczas w Londynie, kreowane były w oparciu o rzut kolisty, w jednym przypadku eliptyczny (Rose, rozbudowany na początku XVII wieku, wkrótce potem zburzony). Wszelkie inne formy: kwadratowe, prostokątne czy trapezowe, były najczęściej doraźnie adaptowanymi przestrzeniami w istniejącej zabudowie mieszkalnej czy usługowej.

W kolistym rzucie można dogodnie dla widza i w miarę efektywnie rozwiązać widoczność, jako podstawowe kryterium dla sprawnego funkcjonowania widowni. Wszelkie inne formy utrudniają lub wręcz uniemożliwiają uzyskanie prawidłowego oglądu sceny z 2 lub 3 poziomów galerii. Przy kształtowaniu linii widoczności w poziomie ,,przeszkadza” rytm słupów nośnych galerii. Odrębnym problemem jest przewyższenie rzędów na 2 i 3 poziomie galerii. Im wyżej, tym bardziej rośnie krzywa logarytmiczna, co w efekcie utrudnia widzom dojście do najwyższych rzędów. W rekonstrukcji londyńskiego Globe dla rozwiązania widoczności na galeriach autor posłużył się kompromisem. Polega on na założeniu przemienności siedzisk (co „pół” widza) i na ukośnym ukształtowaniu dojść do 
rzędów, oraz, co oczywiste, założeniu częściowego braku widoczności z części galerii najbliższych scenie. Problem poziomej i pionowej widoczności przesądza o przydatności innych form rzutu poza kolistą dla teatru szekspirowskiego.

Wzorem teatrów starożytnych, obiekt elżbietański, jako otwarty, stwarza dogodne warunki akustyczne w zamkniętej kolistej formie rzutu. Doraźne „, zamykanie” tej przestrzeni zadaszeniem powoduje całkowitą zmianę warunków akustycznych oraz wydzielenie nieprawidłowej kubatury przypadającej na 1 widza. Może zatem zaistnieć niekorzystny czas pogłosu znacząco obniżający komfort słyszalności.

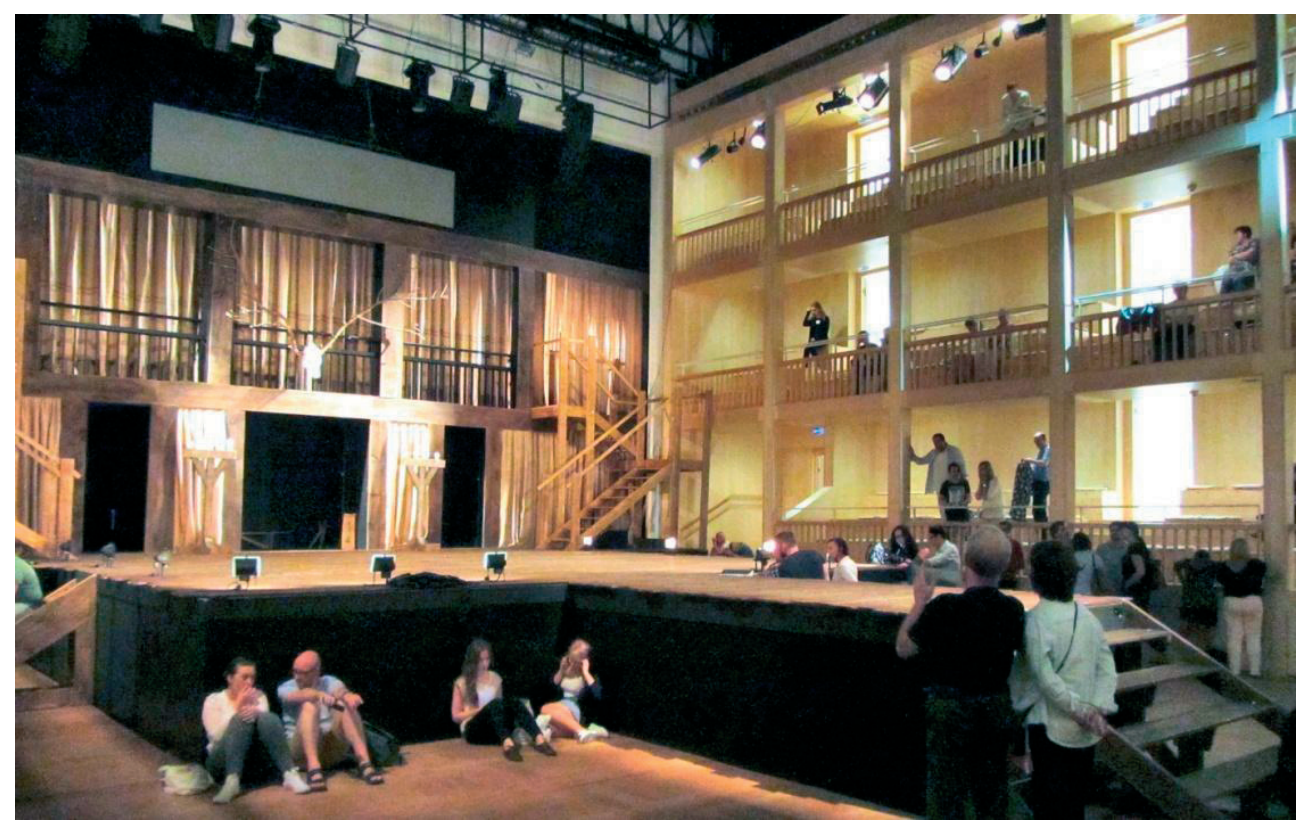

Rys. 5. Wariant sceny szekspirowskiej w Theatrum Gedanense wg. arch. Renato Rizziego, zdjęcie własne autora

Problem taki zaistniał w oddanym do użytku w 2013 roku, gdańskim Theatrum Gedanense. Ideą powstałej w 1990 roku fundacji była rekonstrukcja nieistniejącej szkoły fechtunku. Według nielicznych źródeł historycznych w obiekcie wystawiały przedstawienia angielskie trupy teatralne. Kwadratowa forma dziedzińca otoczonego galeriami z 4 stron, narzuca skojarzenia $\mathrm{z}$,teatrem w stylu elżbietańskim”. Rycina domniemanego autorstwa Petera Willera, nadwornego architekta króla Władysława IV, jest jedynym źródłem, na podstawie której można dochodzić funkcji obiektu. Ewentualna istniejąca na dziedzińcu scena jest niewiadomą, podobnie jak frons scenae, jak i galerie.

Rekonstrukcja obiektu wydaje się wspaniałą ideą, należałoby oczekiwać teatru, który mógłby pełnić rolę przybytku kultury nadającego ton życiu teatralnemu w kraju. Tymczasem wzniesiono obiekt, który ze względu na brak widoczności z większości miejsc na galeriach i wadliwą akustyk przy zamkniętym dachu, nie może spełniać roli sceny szekspirowskiej. Co najmniej dyskusyjna jest funkcja sceny pudełkowej znajdującej się w tle elżbietańskiego podestu, utworzonego zapadniami. W jego miejsce ustawia się rzędy siedzisk, z których możliwa jest obserwacja „, pudełka do podglądania”, ponieważ z galerii taka możliwość istnieje tylko w 1 poziomie, i to z pierwszego i częściowo drugiego rzędu. 
Sceny włoska i elżbietańska są sobie całkowicie obce. Dogodne warunki inscenizacyjne sceny elżbietańskiej wykluczają scenę pudełkową poprzez zupełnie różny ogląd sceny. Do tego należy jeszcze dodać słyszalność przy tej samej kubaturze sali, ale przy zmniejszonej liczebności widzów o około połowę.

Idea połączenia tych dwu funkcji okazała się wyjątkowo niefortunna. Gdański przybytek kultury o ograniczonych możliwościach inscenizacyjnych zaliczyć należy do „Elizabethan-in-Style-Theatre", czego nie ratuje otwierany dach, który z pewnością stal się atrakcją turystyczną, ale teatru nie tworzy.

\section{Synteza przestrzeni zmiennej Petera Brooka}

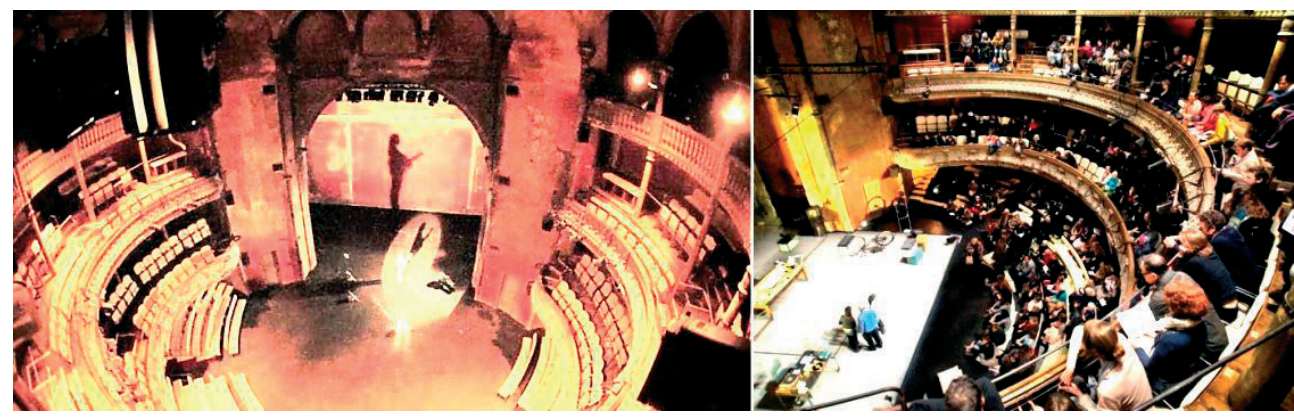

Rys. 6. Les Bouffes du Nord Petera Brooka w dwu odsłonach: (zbliżonej do) włoskiej z ekspozycją proscenium, i szekspirowskiej, przy odpowiednich założeniach twórczych formy nie wykluczają się, zdjęcia: archiwum własne

Poszukiwania formy zamkniętej tworzącej warunki inscenizacyjne zbliżone do szekspirowskich/elżbietańskich, można podsumować podparyskim Les Bouffes du Nord Petera Brooka. Poprzez zrównanie poziomu I rzędu z otwartą sceną, kontakt widza z aktorem jest wyrazisty, bardziej odczuwalny przez uczestników. Peter Brook „robił” teatr dla siebie, architektura sceniczna wynikła $\mathrm{z}$ jego potrzeb. Obiekt został poddany głównie pracom konserwatorskim w takim stopniu, ażeby nie naruszały istniejącej struktury.

Z założeń Brooka wynika, że zależało mu na zachowaniu obiektu w stanie takim, w jakim go zastał. Prace renowacyjne przeprowadzone zostały w 1974 roku i ograniczały się głównie do zabezpieczenia stanu technicznego obiektu. W rzeczywistości, tą jedyną substancją, która dla niego stanowiła wartość, była mogąca tam zaistnieć przestrzeń teatralna, jej podporządkowane zostało wszystko. Teoretycznie jest to układ widowni ze sceną otwartą, natomiast inscenizator prostymi środkami może ją aranżować w dowolnym wariancie. Opierając się na rysunkach zachowanych w archiwum obiektu, układ sali z 1876 roku nawiązywał do barokowej włoskiej. Z zachowanych przekrojów osiowych sali wyni$\mathrm{ka}$, iż widownia $\mathrm{z}$ dostępem do poziomu $\pm 0,0$ posiadała przewyższenie wykonane po ciesielsku. Trzy poziomy balkonów były standardowo skorelowane ze sceną pudełkową, tak, jak robiono to w większości obiektów wywodzących się od włoskiego teatru barokowego. Proscenium w formie wycinka koła było w niewielkim stopniu wysunięte (ok. $3 \mathrm{~m}$ ). Po rozebraniu „parterowej” widowni, Brook uzyskał otwartą przestrzeń, gdzie można dowolnie aranżować widowisko, np. sadzając widzów tylko na galeriach. Po „rozbiórce” parteru, jedynym budowlanym elementem, tyle że mobilnym, systemowym, a więc łatwo demontowanym, są trzy moduły widowni, które w dowolnej konfiguracji można ustawić na płaskiej płycie podłogi zrównanej poziomem ze sceną. Nadto w nadsceniu podwieszony został ruszt, a na obwodzie widowni dwóch górnych poziomów balkonów, zamontowane 
zostały prowadnice dla świateł.,Wystrój” wnętrza utrzymano w takim stanie, wjakim je zastano. Ze strony ludzi teatru, którzy wspólnie w P. Brookiem ,zasiedlali” wówczas obiekt, padały cierpkie uwagi co do przydatności sceny dla teatru, stan budynku określano, jako będący pomiędzy remontem a zburzeniem. Mistrz konsekwentnie i metodycznie zrywał więzy łączące go z teatrem ,gładkim i pięknym”, zmierzał w kierunku ubogiego, pojmując jednakże tę ideę nieco inaczej, aniżeli J. Grotowski. Podkreślał, że teatr zaczął się od rytuału, stawiał na teatr widza i aktora, odchodził od dekoracji ( wszelkich), kładąc nacisk na kostium, i stawiał na jedyną dla niego istotną zdobycz XX wieku - światło. Ta idea „teatru ubogiego" została jakby mimochodem wyeksponowana w paryskim Les Bouffes. Brook widzi swój „ubogi” teatr przez pryzmat starożytności. Zachowując chronologię wydarzeń należałoby najpierw omówić „teatr esencji”, później ,wielką syntezę” mistrza, jako jego credo twórcze. Ale Brook pozostaje na przestrzeni wielu lat taki sam, przekonanie do przestrzeni starożytnego i elżbietańskiego teatru wyraźnie dominuje w jego bogatej twórczości.,,Tymona ateńczyka” mistrz wziął na warsztat nieprzypadkowo. Jest prawie pewne, że Shakespeare nigdy scenicznie nie zrealizował tego dramatu. Rzadko bywał grywany współcześnie. Jak zgoła wszystkie dramaty stradfordczyka, jest to teatr widza i aktora. Robi wrażenie nieukończonego, ze względu na niedopowiedzenia porównywany z „Juliuszem Cezarem”. Poprzez realizację „Tymona” Brook podjął swoiste wyzwanie. Uzupełnił opowieść Shakespeare’a i przybliżył starożytność czasom króla Ludwika XIV. W 1666 roku Molier napisał i wystawił „Mizantropa” na dworze w Wersalu, w nieukończonej jeszcze sali tamtejszego teatru. Tytułowa postać jest po części odbiciem samego komediopisarza. Shakespeare nieco łagodniej potraktował postać Tymona, mino, że podobnie jak około 60 lat później. Molier przypisał swojemu bohaterowi mizantropię. Reżyser unikał Moliera, „dworskość” nie pasowała do jego wizji teatru. „Tymon”, przetłumaczony na język teatralny mistrza, był pełną realizacją jego poglądów. Odszedł całkowicie od teatru Artaux, „wpisując” się w sztukę Jaquesa Copeau. Widzenie teatru jest bliskie klasyce, tej która odpowiada dzisiejszym wyobrażeniom o antycznym przedstawieniu. Surowość wnętrza ,zakonserwowane” liszaje i pleśń na ścianach, zaniedbany, często uszkodzony detal, tworzyły naturalną scenerię dla przedstawienia. Wnętrze sali sprawia wrażenie gigantycznej, tak że można zapomnieć o przestrzeni ograniczonej ścianami i plafonem. Taka wizja teatru wydaje się górować nad wszelką inną, która współcześnie podważana jest przez „nieteatralne” media. Granica między tym co teatralne i „nieteatralne” zaciera się. Przestrzeń Les Bouffes i teatru elżbietańskiego, łączy silna więź, podobnie, jak ten ostatni pozostaje w bliskim związku duchowym i przestrzennym z teatrem klasycznym.

\section{Podsumowanie}

Ujmując Les Bouffes du Nord i inscenizacje Petera Brooka w tym obiekcie nasuwa się skojarzenie z ,synergicznie" pojmowaną przestrzenią teatralną. Dla zrealizowania obiektu o zmiennej przestrzeni mistrz zmieścił się w bardzo niskich kosztach. Zachowana została struktura wnętrza teatralnego, zadbano tylko o te elementy wystroju, które mogłyby mieć wpływ na odczucia widzów lub ujmowałyby sali estetyki. Charakterystyczną brzydotę odrapanych ścian i uszkodzonych stiuków ma przesłaniać dzieło artysty. W trakcie spektaklu ożywa scena, która kreuje swoją własną estetykę. Niskie koszty pierwszej modernizacji i szczególnej w swoim zakresie renowacji z 1974 roku ( 10.000 funtów) wskazują, że pozyskanie takiej właśnie przestrzeni było głównym zamierzeniem mistrza. W podobnych kategoriach należy rozpatrywać teatry renesansowej Anglii, w których „zgrzebność” konstrukcji i formy, indywidualnie współkreowana przez artystę teatru, pozostanie najbliższą niedościgłej-teatrowi antycznemu. 


\section{Literatura}

1. Obracaj P. Sztuka teatru a ewolucja architektury scenicznej. Od wzorów ateńskich po światowa standaryzację włoskiej sceny barokowej. Oficyna Wydawnicza Politechniki Opolskiej, Opole 2007.

2. Hartnoll P., Founda P. (eds.) The concise oxford companion to the theatre. Oxford University Press, Incorporated, Oxford 1992.

3. Braun K. Wielka reforma teatru w Europie, ludzie - idee - zdarzenia. Zakład Narodowy im. Ossolińskich, Wrocław-Warszawa-Kraków-Gdańsk-Łódź, 1984.

4. Mackintosh I. Architecture, actor and audience. Routledge, London and New York, 1997.

5. Osterloff B., Koecher-Henzel A. Polska plastyka teatralna, ostatnia dekada. Instytut Sztuki Polskiej PAN, Warszawa 1991. 
